\title{
粰 \\ IS LADY JUSTICE BLIND? READING BRAZIL'S 2012 AFFIRMATIVE ACTION DECISION THROUGH THE STRUGGLE FOR GENDER EQUALITY \\ A DONA JUSTIÇA É CEGA? LENDO A DECISÃO DE AÇÃO AFIRMATIVA DE 2012 NO BRASIL ATRAVÉS DA LUTA PELA IGUALDADE DE GÊNERO
}

Travis Knoll ${ }^{1}$

"The color of one's skin is like the gender that one carries or your place of birth - [one's] geographic origin." - Carlos Aryes Britto, Brazilian Supreme Court (STF) President (04/2012-

"In a democracy, we do not give to each individual that which is theirs, but rather, adopt policies to give to each according to their needs." - Cármen Lúcia, STF Minister (Current

President 2017)

\begin{abstract}
Brazil has boldly embraced affirmative action on a scale never before attempted in in the Americas. Despite this innovation, scholars have not analyzed this surprising development in a rigorous and grounded fashion. This essay seeks to delve deeper into the Brazilian Supreme Court's (STF) 2012 decision (acórdão) to uphold the University of Brasilia's racial quota system against allegations by the conservative Democrat Party (DEM). The DEM argued that such a system of affirmative discrimination violated a "fundamental [i.e. constitutional] precept", a procedure of relief and remedy that serves as a last resort for resolving constitutional disputes. The unanimous decision came as surprise to most Brazilian observers both for its broad ideological consensus and for its explicit endorsement of racial quota policies in a country that still widely regarded itself as relatively free of racial tensions and biases. Closely analyzing the judges' final opinions (votos), this essay makes the case that the decision's unanimity came from a constellation of metaphors and constitutional philosophies. These metaphors and philosophies, at times in tension, coalesced to form a coherent defense of protected identity classes and the state's duty to protect them. In fact, the decision served to converge two categories of affirmative action that previously had operated on parallel tracks: Racial and gender quotas. Finally, each vote relied on concepts of difference and equality (in the feminist sense) to arrive at a decision favorable to quotas.
\end{abstract}

Keywords: Supreme Court. Affirmative action. Race. Feminism. Equality. Identity.

Resumo: O Brasil adotou ação afirmativa numa escala nunca antes tentada nas Américas. Apesar dessa inovação, pesquisadores ainda não analisaram, de maneira rigorosa e fundamentada, esse acontecimento surpreendente. Este artigo pretende aprofundar-se no acórdão do ADPF do Supremo Tribunal Federal que decidiu de forma unânime manter o sistema de cotas da Universidade de Brasília (UnB) contra a alegação do Partido Democratas (DEM) de que tal sistema violava preceito fundamental da constituição (a ADPF é

\footnotetext{
${ }^{1}$ History PhD student at Duke University (travis.knoll@duke.edu).
} 
remédio jurídico que serve como último recurso na resolução de controvérsia constitucional). A decisão surpreendeu tanto por seu amplo consenso quanto pelo apoio explícito às cotas raciais num país que ainda se vê livre de tensões e preconceitos raciais. Analisando detalhadamente os votos dos ministros, este estudo argumenta que a unanimidade da acórdão procedeu de uma constelação de metáforas e filosofias constitucionais. Tais metáforas e filosofias, às vezes operando em tensão, coalesceram para formar uma defesa coerente dos direitos de grupos identitários e do dever do Estado de protegê-los. Na realidade, o acordão conseguiu convergir linhas de ação afirmativa que vinham operando em trilhos separados: as cotas de raça e de gênero. Enfim, cada voto recorreu aos conceitos de diferença e igualdade (no sentido feminista) para chegar a uma decisão favorável às cotas.

Palavras-chaves: Supremo Tribunal Federal. Ação afirmativa. Raça. Feminismo. Igualdade. Identidade.

\section{Introduction}

Brazil has boldly embraced affirmative action on a scale never before attempted in the Americas. Despite this innovation, scholars have not analyzed this surprising development in a rigorous and grounded fashion. This essay seeks to delve deeper into the 2012 decision (acórdão) of the Brazilian Supreme Court (STF) to uphold the racial quota system of the University of Brasilia (UnB) against allegations by the conservative Democrat Party (DEM) that such a system of affirmative discrimination violated a "fundamental [i.e. constitutional] precept", a procedure of relief and remedy that serves as a last resort for resolving constitutional disputes. ${ }^{2}$ The unanimous decision came as a surprise to most Brazilian observers both for its broad ideological consensus and for its explicit endorsement of racial quota policies in a country that still widely regarded itself as relatively free of racial tensions and biases.

The DEM's petition argued that formal equality before the law created a harmonious society and that positive discrimination would tear the national fabric asunder. UnB's response argued that both the spirit and the letter of Brazil's founding documents rested on society's ability not just formally to stop, but also to repair, lasting and continuing damage to the most vulnerable members of Brazil's body politic. So with Brazil's national identity at stake and such a wide range of judicial philosophies, why did the judges feel the need for unanimity? What logics and tradeoffs produced this seemingly resounding result?

Using the judges' final opinions (votos), this essay makes the case that the decision's unanimity came from a constellation of metaphors and constitutional philosophies. These metaphors and philosophies, during times of tension, coalesced to form a coherent defense of

\footnotetext{
${ }^{2}$ Those alleging a "Case of Violations of Fundamental Precepts (ADPF)" must specify the alleged constitutional violation, provide proof for said violation, prove that the act violated the fundamental rights of the accused, a specific request for relief, and any relevant court rulings or debates pertaining to the alleged violation. The Court reviews ADPFs only after the alleged victim exhausts all other legal remedies. For further elaboration, see "Article 3: I-V, Article 4, 1. Lei 9.882. Dezembro de 1999. Disponível em: http://www.stf.jus.br/portal/legislacaoAnotadaAdiAdcAdpf/verLegislacao.asp?lei=1. Acesso em: 15 mar. 2017.
} 
protected identity classes and the state's duty to protect them. In fact, the decision served to converge two categories of affirmative action that previously had operated on parallel tracks: Racial and gender quotas. This convergence proved important, because gendered analogies and metaphors allowed many of the STF's ministers to reconceptualize Brazil's racial inequalities in ways that would conform to, rather than disrupt, Brazil's national narrative. The complex network of sociability among the ministers and social actors and among the justices themselves played a role not only in the rationale of each opinion, but also in the margin of victory for racial quota policies in court.

This essay will first briefly describe the case itself and the structure of the document it analyzes. It will then place the decision in the larger context of policy and historical debates surrounding gender and racial quotas. It will then provide an analysis of each judge's decision (or lack thereof) and how each opinion drew on ideas of difference and equality in arriving at the decision to support the quotas. The essay will end with a few questions about the decision's potential impact in Brazil's present political environment.

\section{ADPF 186: The Case}

The final decision was in fact a synthesis of years of documentation. The case documents run over 2000 pages from April 17, 2006 to April 26, 2016. The case documents center on a 612page DEM petition and an 80-page response by the University of Brasilia (UnB). A set of thirdparty documents sought to inform and influence the opinions of the court. Some offered opinions in their capacity as government agencies. Others filed as "friends of the court" citing the "democratization" of the Supreme Court's deliberative process (the Brazilian legal system adopted this legal form in 1999 when they standardized the process for challenging the constitutionality of laws). ${ }^{3}$ Included in the case were government legal offices, such as Brazil's attorney general (AGU), inspector general (PGR), and General Public Defender (DPGU). These documents offered technical legal advice on how affirming or denying racial quotas would affect their various missions. Government cultural agencies such as the National Indian Foundation (FUNAI) and the Palmares Foundation (a Ministry of Culture institution that promotes/preserve African-Brazilian culture) also weighed in to support the policies, which converged with their mandates to advance the interests of Indigenous and Afro-Brazilian communities. The then-ruling Worker's Party (PT) also weighed in, as did the country's largest union, the Central Worker's Union (CUT-DF). Social movements such as the UnB's student union (DCE-UnB), various

\footnotetext{
${ }^{3}$ Friends of the court fall under three categories. 1. "Those who seek to protect the rights of others [a tutela de interesses ou direitos de outrem], and can influence the outcome of the case", 2. Those "outside the process called by the presiding judge to give information or clarify technical or even legal questions pertinent to the facts of the case" and 3. "[Specifically for the Supreme Court] representative natural, juridical persons or specialized entities with competency to weigh in on directly relevant matters of the constitutional debate". See "Amicus Curiae" In: GLOSSÁRIO JURÍDICO, Supremo Tribunal Federal. Disponível em: http://www.stf.jus.br/portal/glossario/verVerbete.asp?letra=A\&id=533. Acesso em: 16 mar. 2017.
} 
human rights institutes, and African Brazilian movement organizations - EDUCAFRO and Unified Black Movement (MNU) - also threw their support behind the policies. While this article will not analyze any of these briefs in detail, they played a foundational role in shaping the judges' reasoning and legitimizing the case as a forum for pluralistic, historical, philosophical, and political debate.

\section{Race and Gender Quotas: Getting from Parallel to Intersecting Tracks}

The historical debates surrounding affirmative action remain as new as the policies themselves. However, followers of the policy and historical questions surrounding quotas can easily distinguish separate sets of questions raised when dealing with either gender or racial quotas.

Questions centering on the permissibility and roots of affirmative action characterized the debates over racial quotas. Some historians and sociologists debated Brazil's legacy of slavery, the constitutional meaning of equality, and the driving forces behind the policies. Some scholars argued that affirmative action efforts started locally with the rise of black movements. Others cited international and national examples of quotas, such as Franklin Roosevelt's and Getúlio Vargas' labor laws. ${ }^{4}$ For some, the combination of data and militancy drove affirmative action's rise. Marcelo Paixão, an important Brazilian public intellectual and sociologist, wrote in 2004: "Statistics produced recently are the result of pressure by the black movement". 5

The debate over affirmative action went to the heart of a long-running debate, both in the U.S. and Brazil, about the level of brutality applied in each system of slavery and what debt, if any, society owed as a result. Some earlier historians of Brazil saw racism as an imperial problem, a vestige of the ancient regime. Following in the footsteps of intellectuals who proclaimed a racially enlightened Brazil, Roger Bastide condemned the backwardness of the previous generation of slaveholders, while proclaiming that Brazil had moved from a "negative" Eurocentrism to a "scientific" view of race relations by "proclaim[ing] the equality of all citizens, regardless of skin color or ethnic origin". ${ }^{6}$ The most notable historians and sociologists in Brazil, first from Bahia and Recife, and later from the University of São Paulo, gained notoriety by attempting to determine the origins, strength, and comparability, of racial discrimination in

\footnotetext{
${ }^{4}$ Valter Roberto Silvério, “Ação afirmativa e o combate ao racismo institucional no Brasil”. Cad. Pesqui. [online], v. 117, p. 227, 230, 2002; MOEHLECKE, Sabrina. "Ação afirmativa: história e debates no Brasil." Cadernos de pesquisa, v. 117, n. 11, p. 203-204, 2002; Legal commentator and affirmative action critic Antonio Celso Baeta Minhoto agreed with these general timelines. He traced affirmative action back to Franklin Roosevelt's fair labor laws and later, to 1960s Brazilian labor laws seized on by black activists in the 1970s. Minhoto also saw affirmative action as a mechanism of state intervention to protect vulnerable populations. MINHOTO, Antonio Celso Baeta. Da escravidão às cotas. São Paulo: Boreal, 2013, p. 5, 65, 95.

${ }^{5}$ Marcelo Paixão. "Waiting for the Sun: An Account of the (Precarious) Social Situation of the African Descendant Population in Contemporary Brazil." Journal of Black Studies, v. 34, n. 6, p. 743, 2004.

${ }^{6}$ Roger Bastide, The African Religions of Brazil: toward a Sociology of the interpenetration of Civilizations.

Baltimore: Hopkins University Press, 1978, p. 140.
} 
Brazil. $^{7}$ So, in a real sense, history was present for the litigants.

The historical role of the United States in formulating racial theories (and responses to them), also played a significant role in the case. Many of the studies of racism in Brazil came from U.S. historians that wanted to answer a question that had dogged UNESCO's researchers in Brazil during the 1950s: Did discrimination exist in Brazil, and if so, how did it compare with the U.S.A.'s segregationist system? ${ }^{8}$ Far from isolated Brazil's academic theories, they often wrestled with these questions jointly with their Brazilian colleagues. ${ }^{9}$ At the heart of this legal action lay the question: What is Equal Protection (the Fourteenth Amendment in the U.S. and Article III in Brazil's Constitution)? Behind that legal question laid another even more politically and historically fraught question. Where lay the origins of racism? Scholars ostensibly opposed to U.S. imperialism, bristled at the idea that black activists in Brazil would draw on the U.S. Civil Rights movement, alongside de-colonialization efforts in Angola and Mozambique. The DEM's petition used this anti-U.S. critique to argue that affirmative action merely constituted a U.S. export of its racial theories to the rest of the world. ${ }^{10}$ Ironically, the DEM had no problem citing in the same brief comparative historian Carl Degler, the "anti-racist" Gilberto Freyre, noted historian of race John Hope Franklin, and even Martin Luther King's "I Have A Dream" speech, to affirm the superiority of Brazil's race relations and extol the virtues of colorblindness. ${ }^{11} \mathrm{UnB}$ also launched its brief with a citation of King's "Why We Can't Wait" dismissing the notion that blacks being free ipso facto bestowed equality upon them. ${ }^{12}$

\footnotetext{
${ }^{7}$ The main works of the São Paulo school during the mentioned period are the following: Fernando Henrique Cardoso, Capitalismo e escravidão no Brasil meridional: o negro na sociedade escravocrata do Rio Grande do Sul (Rio de Janeiro: Difusão Européia do Livro , 1962). See also: Florestan Fernandes, A integração do negro na sociedade de classes. I, O legado da "raça branca ([S.I]: Dominus Editoria, 1965).

${ }^{8}$ Jean M. Hébrard, "Slavery in Brazil: Brazilian Scholars in the Key Interpretive Debates." Translating the Americas v. 1, p. 52-53, 2013. Disponível em: https:/quod.lib.umich.edu/cgi/p/pod/dod-idx/slavery-in-brazilbrazilian-scholars-in-the-key-interpretive.pdf?c=lacs;idno=12338892.0001.002. Acesso em: 9 maio 2017.

${ }^{9}$ Frank Tannenbaum, Slave and Citizen (Boston: Beacon Press, 1946); Carl Degler, Neither Black nor White: Slavery and Race Relations in Brazil and the United States (New York: Macmillian, 1971); Robert Toplin, The Abolition of Slavery in Brazil (New York: Atheneum, 1972), 117-118n. Although Toplin would not enter into direct dialogue with the structural questions raised in Brazilian historian Emilia Viotti da Costa's first book, he would cite her, Robert Conrad, Florestan Fernandez, Sergio Buarque de Holanda, Octavio Ianni, and Stanley Stein for their contributions to the manuscript.

${ }^{10}$ The argument that affirmative action constitutes a U.S. imposition (self-imposed or otherwise), had remained a continuing debate, even among traditionally progressive history and sociology scholars in the decade leading up to the decision. Pierre Bourdieu and Loic Wacquant, "On the Cunning of Imperial Reason". Theory, Culture, and Society, v. 16, n.1, p.44, 1999. The author also adds "book sales, for a lack of success based on intellectual esteem" as another sordid motive for exporting this model (p. 44-45). See historian John French's response: John D. French, "Passos em Falso da Razão Antiimperialista: Bourdieu, Wacquant, e o Orfeu e o Poder de Hanchard". Estudos AfroAsiáticos, Ano 24, n. 1, p. 97-140, 2002.

${ }^{11}$ DEM, "Petição Inicial.", ADPF 186. Supremo Tribunal Federal, 1,3,40, 49, 53,58, 187. For King's full speech (of which the DEM brief cites part on page 1) see: King, Martin Luther Jr., "'I Have a Dream'. Address delivered at the March on Washington for Jobs and Freedom". The Martin Luther King, Jr. Research and Education Institute (Stanford University). Disponível em: https://kinginstitute.stanford.edu/king-papers/documents/i-have-dreamaddress-delivered-march-washington-jobs-and-freedom. Acesso em: 16 mar. 2017

${ }^{12}$ UnB, ADPF 186.” Respota do Despacho”. Supremo Tribunal Federal, 628. An English translation of the passage cited in UnB's draft can be found in King, Martin Luther King Jr., Why We Can't Wait (New York: A Mentor Book/New American Library, 1964), 134. As excerpted by the King Legacy Series at Rutgers University. Disponível em: http://rcha.rutgers.edu/images/2016-2017/1960s/Documents/11.-RCHA-2016-The-Culture-of-the-SixtiesMartin-Luther-King-Jr.-Why-We-Cant-Wait-condensed-1963.pdf. Acesso em: 16 mar. 2017.
} 
Unlike racial quotas, gender quotas did not meet with stiff public (albeit minority) opposition to notions of "compensatory justice" and collective equality. Instead, authors - many times feminist scholars - questioned the very efficacy of the gender quota systems whether because of their basis in current meritocracy or the danger that identity per se would outweigh the quality of candidates' political projects. ${ }^{13}$ Other feminist scholars focused on the importance of difference and the dangers of formalistic egalitarian discourse either because such discourses boxed radicals into mainstream political projects or as an attempt to fight a "melting pot" or mestiçagem narrative that would undercut identity itself. ${ }^{14}$ History, origins, and means of justice mattered as much to these scholars as the practical outcome of increased access of protected classes to higher education.

As the court process unfolded, scholars such as Silvério, Clio Nudel Radomysler, Evandro Duarte, and Guilherme Scotti dealt with the complex relationship between the courtroom, the judges that presided over it, and the social stakeholders that argued in it. ${ }^{15}$ This essay's analysis of the court's final decision both builds on this latest scholarship tying social movements to legal advances and argues that ministers' decisions relied on converging discussions of racial and gender inequalities, inequalities that have often been treated as empirically parallel with only a nod toward the occasional theoretical usefulness of one category to the other. This essay, in tracing the contributions of masculine discourses and feminist theory to justifications for racial affirmative action, accounts for "the need to account for multiple identities when considering how the social world is constructed". ${ }^{16}$ In short, this essay tracks how one key case in Brazilian jurisprudence developed notions of intersectionality to advance a specific racial and gender determined public policy.

\section{The Case Report: Setting the Stage or Tipping the Scales?}

\footnotetext{
${ }^{13}$ Clara Araújo, "Potencialidades e limites da política de cotas no Brasil”. Estudos Feministas, p. 231-244, 2001; Paula Patr. Helga, "A Política De Cotas Para Mulheres no Legislativo, o Feminismo e as Ações Afirmativas." Revista de Administração Pública, v. 38, n. 6, p. 1116-1118, nov. 2004. For Araújo's previous work on women in politics, see: Araújo, Clara. "Mulheres E Representação Política: A Experiência Das Cotas No Brasil." Estudos Feministas 6, no. 1 (1998): 71-90. Araújo has in recent years moved toward a comparative historical approach to highlight problems faced by Brazilian women in politics. See: Araújo, Clara, "Rotas de ingresso, trajetórias e acesso das mulheres ao legislativo-um estudo comparado entre Brasil e Argentina" Estudos Feministas v. 18 , n. 2, p. 567-584, maio/ago. 2010.

${ }^{14}$ Rosiska Darcy de Oliveira and Peggy Sharpe (Trans.), In praise of difference: the emergence of a global feminism (Piscataway, NJ: Rutgers University Press, [1998] 2000), 42; Sandra Azeredo, "Mestiçagem, igualdade e afirmação da diferença-pensando a política das cotas na universidade." Estudos Feministas, Florianópolis, 13:3 (Sept.-Dec. 2005):741, 745. Fúlvia Rosemberg, and Leandro Feitosa Andrade. "Ação afirmativa no ensino superior brasileiro: A tensão entre raça/etnia e gênero." Cadernos Pagu Vol. 31 (2008): 424-428, 435. Some scholars, while claiming affirmative action policies "created" racial binaries in the 1990s argue that difference played a key and constructive role in redistributing social capital. See: Mountian, Ilana, and Elena Calvo-Gonzalez. "II.'Race', class and affirmative action in Brazil: Reflections from a feminist perspective." Feminism \& Psychology Vol. 22, no. 2 (2012): 240-248.

${ }^{15}$ Silvério, Valter Robeerto, As cotas para negros no tribunal: A audiencia pública do STF (São Carlos: EDUSFCar, 2012); Duarte, Evandro Piza and Guilherme Scotti, "História e memória nacional no discurso jurídico: o julgamento da ADPF 186." Universitas JUS 24:3 (2013): 33-45; Radomysler, Clio Nudel, "STF: Um espaço de luta do movimento negro." Revista Direito e Práxis 4:6 (2013): 31-51.

${ }^{16}$ Kimberle Crenshaw, "Mapping the Margins: Intersectionality, Identity Politics, and Violence against Women of Color." Stanford Law Review, 43,6 (Jul. 1991): 1245.
} 
The court decision involved ten Supreme Court ministers (with one minister recusing). The court itself tilted center-left, with eight out of eleven ministers appointed by presidents President Luiz Inácio "Lula” da Silva and Dilma Rousseff of the Worker's Party (PT) -- pioneers of federal university expansion and access. The court had only two women and one Afro-Brazilian minister. Included below is a table containing information on partisan political leanings, the day each minister took office, the race, and the gender of each justice, as well as their vote on DEM's petition (a "no" vote would uphold UnB's policy). I have listed the ministers in the order that they cast their votes.

\begin{tabular}{|l|l|l|l|l|l|l|}
\hline \multicolumn{9}{|c|}{ Supreme Tribunal Ministers at a Glance (April 2012) } \\
\hline Name & Assumption (dd/mm/yyyy) & Appointed By (Name, Party) & Nominating Party Lean & Gender & Race & Vote on ADPF \\
\hline Ricardo Lewandowski & $16 / 03 / 2006$ & L. I. Lula da Silva (PT) & Center-Left & Male & White & No \\
\hline Luiz Fux & $3 / 3 / 2011$ & D. Rousseff (PT) & Center-Left & Male & White & No \\
\hline Rosa Weber & $19 / 12 / 2011$ & D. Rousseff (PT) & Center-Left & Female & White & No \\
\hline Cármen Lúcia & $21 / 06 / 2006$ & L. I. Lula da Silva (PT) & Center-Left & Female & White & No \\
\hline Joaquim Barbosa & $25 / 06 / 2003$ & L. I. Lula da Silva (PT) & Center-Left & Male & Black & No \\
\hline Cezar Peluso & $25 / 6 / 2003$ & L. I. Lula da Silva (PT) & Center-Left & Male & White & No \\
\hline Gilmar Mendes & $20 / 06 / 2002$ & F. H. Cardoso (PSDB) & Center-Right & Male & White & No \\
\hline Marco Aurélio Mello & $13 / 06 / 1990$ & F. Collor de Mello (PRN) & Conservative & Male & White & No \\
\hline José Celso de Mello & $17 / 08 / 1989$ & J. Sarney (PMDB) & Center & Male & White & No \\
\hline Carlos Ayres Britto & $25 / 06 / 2003$ & L. I. Lula da Silva (PT) & Center-Left & Male & White & No \\
\hline Dias Toffoli & $23 / 10 / 2009$ & L. I. Lula da Silva (PT) & Center-Left & Male & White & Recuse \\
\hline
\end{tabular}

There are a few things that stand out in this table. Judges nominated by the Center-Left presidents cast their votes earliest. The more senior ministers, often more conservative, voted last (with the STF president as the exception). Since either side needed six votes to triumph and since each vote occurred in real time, voting together as a bloc, PT-nominated judges could decide the case before conservatives could present their full cases. Conservative justices would then have to change their vote or explain their dissent on a highly controversial issue publicly with the case already decided. Thus, arguing that conservative ministers voted strategically not to be "on the wrong side of history" or in the minority constitutes a viable interpretation and fits with notions of law-as-performance and Brazilian elites' desires to project public social harmony. That said, conservative justices would not want to seem to bow to merely political pressures. Such an interpretation does not take seriously the reasoning of each minister nor his or her ability intellectually to evolve in a dynamic environment and does not seem productive given the rich documentary sources presented here. To this aforementioned political and demographically composed STF, Minister Ricardo Lewandowski, as case rapporteur, opened his summary report.

The rapporteur's report serves by definition to "direct the rest of the justices in the court in their analysis of the controversy before them". ${ }^{17}$ The rapporteur then casts his or her vote after reading prepared remarks (if any) separate from the report. Other judges follow a similar procedure in which they have the opportunity to make commentary before reading their opinion

\footnotetext{
${ }^{17}$ See, "Relator” In: Glossário Jurídico, Supremo Tribunal Federal. Disponível em: http://www.stf.jus.br/portal/glossario/verVerbete.asp?letra=R\&id=212. Acessso em: 15 mar. 2017. The rapporteur is generally responsible for summarizing the case, including all relevant filings up until the point of the final decision. In extraordinary cases, the rapporteur may unilaterally decide a case. The court distributes cases on a rotating basis in accordance with internal governance mechanisms. Because the decisions are read aloud, the acórdão serves as a type of transcript of conversation and not merely a compilation of judicial decisions. It highlights the comity of the court, which allows for back-and-forth, and even interruptions, that eschews a mechanical decorum.
} 
from the bench. ${ }^{18}$ In short, Lewandowski, appointed by former President Lula da Silva, had a unique opportunity to frame the questions and agenda before the court and did end up authoring the final decision. ${ }^{19}$ Lewandowski started by summarizing the DEM petition, which alleged that UnB policies providing housing and special admissions slots to indigenous and African Brazilian students violated a host of Equal Protection Clauses of Brazil's detailed constitution. ${ }^{20}$ After verifying that the petitioner had exhausted all previous legal remedies, Lewandowski, responsible for presenting the case to the court, summarized both positions.

Lewandowski highlighted the petitioner's (DEM) caveat that they did not wish to "(a) discuss, in this ADPF, the constitutionality of affirmative action [as] a necessary policy for minority inclusion. (b) No one is arguing over whether Brazil should adopt a Social State model; (c) no one denies the existence of racism, prejudice, and discrimination in Brazilian society". Lewandowski's report highlighted the contradiction of these seemingly reasonable caveats by turning immediately to the DEM's assertion that the UnB policies would run the "danger" of establishing "institutional racism" in the mold of the United States, South Africa, and Rwanda," that "racial affirmative actions are not necessary in the country," and that "no one is excluded, in Brazil, for simply being black". ${ }^{21}$ Lewandowski also highlighted DEM's concern that "compensatory justice" would force Brazilians to pay for "injustices and failures committed against individuals in the past" without knowing who in the present deserved redress given alleged inflation of Brazil's black demographic percentage and the alleged complexity of Brazil's multiracial classifications. ${ }^{22}$ In short, the DEM's characterization of Brazil as a melting pot in danger of racialization contradicted its claims to acknowledge that some Brazilians pegged blackness as a negative difference.

The rapporteur then moved to the defendants' (UnB) arguments, which deemed antidiscrimination laws "insufficient for the achievement of equality; [for which] it is fundamental to... combin[e] prohibition against discrimination with policies that promote equality". 23 The UnB further argued that the representational disparity of black Brazilians in public higher education spoke to a "veiled [and] camouflaged" racism, and only "democratizing" quotas could

\footnotetext{
${ }^{18}$ This procedure does not have the same meaning in the United States, where reading an opinion from the bench usually occurs during a dissent and serves to convey extreme displeasure at the majority decision. See: William D. Blake AND Hans J. Hacker, “'The Brooding Spirit of the Law': Supreme Court Justices Reading Dissents from the Bench" The Justice Center Journal v. 31, n.1, p. 1-25, 2010.

${ }^{20}$ Ibid. 3. Those alleging a "Case of Violations of Fundamental Preceptss (ADPF)" must specify the alleged constitutional violation, provide proof for said violation, prove that the act violated the fundamental rights of the accused, a specific request for relief, and any relevant court rulings or debates pertaining to the alleged violation. The Court reviews ADPFs only after the alleged victim exhausts all other legal remedies. For further elaboration, see “Article 3: I-V, Article 4, 1. Lei 9.882. Dezembro de 1999. Disponível em: http://www.stf.jus.br/portal/legislacaoAnotadaAdiAdcAdpf/verLegislacao.asp?lei=1. Acesso em: 15 mar. 2017. ${ }^{21}$ Ibid. 4.

${ }^{22}$ Ibid. 5-6.

${ }^{23}$ Ibid. 7.
} 
begin to remedy long-standing social ills. ${ }^{24}$ The UnB's argument carried weight with the Executive Branch's legal apparatus. The General Prosecutor supported the UnB policies as being in accordance with the 1988 Constitution's endorsement of material equality, and by extension, redistribution and reparations based on past and continuing social discrimination. The Attorney General's office also weighed in citing blatant discrimination in Brazilian society and added that "reserving slots does not exclude other [converging means] toward similar ends". ${ }^{25}$ In short, Brazil's leading law enforcement agencies agreed that discrimination based on sociallyconstructed race discrimination warranted redress through positive discrimination.

Lewandowksi's summaries of the "friend of the court" briefs and the public audience debates highlighted the importance of "pluralizing the constitutional debate" by consulting affected stakeholders (academics, students, unions and social movements) in influencing the affirmative action debate. ${ }^{26}$ The Public Defender argued that most of the legal aid it provided went to vulnerable populations, populations which most benefited from affirmative action policy. Afro-Brazilian human rights institutes and NGOs involved in another state case in which they were involved, the ADI 3.197/RJ, which also challenged racial quotas, also sought entry into the process citing their defense of cultural, racial, and socio-economic justice. The Brazilian MestizoPardo Movement (MPMB) opposed affirmative action policies for not including "all participating groups in the civilizing national project" adding that diversity expanded beyond "indigenous and Afro-Brazilian groups". ${ }^{27}$ Despite this small group's opposition, major government organizations FUNAI and the Palmares Foundation, explicitly created to advance Afro-Brazilian and indigenous cultural rights, challenged DEM's argument that race discrimination per se did not exist in 2012 Brazil. DEM's argument discounted the living reality of the very populations to which these organizations advocated giving "political, social, and economic equality". Furthermore, the organizations saw no contradiction between merit and positive discrimination in the quota system, noting the UnB integrated "cutoff scores" which would ensure minimum academic standards. ${ }^{28}$ The convergence of civil society organizations and government agencies confirmed a strong social consensus rooted in the recognition and respect of positive social differences.

The public audiences allowed for direct live testimony to the court, combining decorum with spectacle sometimes pitting faculty against students. Stare of Rio Grande do Sul's Federal University (UFRGS) anthropology professor, Denise Fagundes Jardim, spoke of the " [positive]

\footnotetext{
${ }^{24}$ Ibid. 8.

25 Ibid. 9-10.

${ }^{26}$ See judgment by Eros Grau in ADPF 73 on August 1, 2005 in the judicial comments on Art. 6 Sec. 2, Lei 9.882.

Dezembro de 1999. Disponível em:

http://www.stf.jus.br/portal/legislacaoAnotadaAdiAdcAdpf/verLegislacao.asp?lei=1;

http://www.stf.jus.br/portal/jurisprudencia/listarJurisprudencia.asp?s1=(73.NUME.\%20OU\%2073.DMS.)\%20NAO\% 20S.PRES.\&base=baseMonocraticas. Acesso em: 16 mar. 2017.

${ }^{27}$ Ibid. 11-13.

${ }^{28}$ Ibid. 15,16 .
} 
socio-structural impact" of affirmative action which "affirmed the collective constitutional rights of those that [had been] relegated to the margins of human dignity". Other professors such as São Paulo University's (USP) Kabengele Munanga, the State of Minas Gerais' Federal University (UFMG) Leonardo Avritzer, and spokesmen for various cultural and human rights organizations argued that affirmative action promoted diversity. Diversity, being not only legal, but also beneficial to society, represented "true democracy". ${ }^{29}$ On the other side lawyer Wanda Marisa Gomes Siqueira and student David Kura Minuzzo (who graduated in September of 2012) argued that racial quotas hurt white students because of the potential for fraud and the lost opportunities for students to seek early admission decisions (preenchimento de vaga) ${ }^{30}$

All in all, the amicus curiae briefs and the public audiences showed that civil society organizations and sympathetic government organizations formed a broad social coalition of support for the quota system - crossing economic, social, and ethnic divides - while the petitioners remained largely isolated, relying on a set of traditional arguments about Brazilian social harmony long since questioned by social scientists. While the UnB argued for an intersectional effect (helping one marginalized group would directly or indirectly help another), the DEM and its supporters highlighted the dangers of emphasizing social difference and advocated the traditional safety and predictability of a homogenous meritocracy. The DEM's supporters argued for a negative form of justice that "protected" the rights of individuals to pursue certain universal rights, while the UnB, government organizations, and the majority of social movements involved in the case advocated for a "right to access" for marginalized groups, access they believed would benefit society as a whole. Lewandowski's report told the story of an imbalance in the legal arguments over quotas. Had Lewandowski's report skewed perceptions, reflected them, or both? A clearer answer might come in seeing how he and the other ministers would actually vote, and why.

\section{The Votes}

Turning to the votes, it's important to remember that each vote in the STF functions as a concurring opinion. Votes are written up beforehand and read from the bench, but the ministers do not work beforehand to form majority or minority blocks and do not normally know the votes of other ministers. The votes in this case centered on a few key rationales. First, a tutelage mentality toward race- and gender-protected classes aided the minister in escaping the exclusively "racial" aspect of the UnB's affirmative action policies. Other ministers similarly conflated gender and racial non-discrimination arguments applying legislation and precedents from both areas. ${ }^{31}$ Other ministers voted in accordance with the principle of redistributive justice (the necessity to remedy current socioeconomic inequalities). Others still focused on the principle of

\footnotetext{
${ }^{29}$ Ibid. 24.

${ }^{30}$ Ibid. $20-21$

${ }^{31}$ Rightly so, I believe given the text of Brazil's constitution describes non-discrimination in sequential clauses.
} 
compensatory justice (repayment for past harm, in this case racism). Finally, others focused on the benefits society gained from disadvantaged groups' participation in the political process.

In addition to presenting the report to the full court, Lewandowski also presented his vote first. He focused on the intersection of gender and racial discrimination and the social benefits of marginalized groups' political participation in deciding to dismiss DEM's petition. He described the 1988 Constitution as a rupture from previous visions of social harmony. Instead of "simply proclaiming the principle of equality in the formal sense [according to Article $\mathrm{V}$ of the Brazilian Constitution]" the constitution sought to "give the maximum effect to this important statement" by guaranteeing "material or substantive equality...taking into consideration-of course-the differences that distinguish [Brazilians and resident foreigners] due to natural, cultural, social, and even accidental reasons" with special attention to "the de facto inequality between "diferente" social groups [italics mine]." ${ }^{32}$ Citing legal scholar Daniela Ikawa, Lewandowski elaborated that "formal equality" that "carries on injustices" refuses to recognize "differences in identity". ${ }^{33}$ Thus, only material equality could give different groups due recognition.

Lewandowski also engaged the long debate over the origins and precedence of affirmative action, pointing out that "affirmative action policies are not a North American creation. They really have their origin in India in 1935 with the "Government of India Act" a society marked by "a rigid social stratification". Connecting racial affirmative action to gender, Lewandowski also noted that former STF judge Sydnei Sanches (1984-2003) upheld as "constitutionally legitimate" affirmative action policies citing at the time the United States' Fair Pay Act (1963) and Civil Rights Act (1964). Rebutting the DEM's claims that UnB's policies gave credence to racial scientific theories, Lewandowski turned toward legal historian António Manuel Hespanha, who argued "the ethnic question presents extremely strong analogies with the gender question" citing the "exportation" of white-Eurocentric "universal categories [applied] to countries to which they were complete foreign" essentially relegating these societies to "unequal relations" as "inferior cultures". ${ }^{34}$ Lewandowski used gender as a vehicle for understanding the contradictions of the suit claiming reverse discrimination by importing Universalist principles in the name of ideological protectionism. By invoking India's quota laws, Lewandowski implicitly nodded to the intersectional oppression of race and class. ${ }^{35}$ This point opposed conservative

\footnotetext{
${ }^{32}$ Ibid. 49. Article V establishes that "all are equal before the law without distinction of any sort, guaranteeing Brazilians and foreign residents in the country the inviolable rights to life, liberty, equality, security, and property..." Disponível em: http://www.planalto.gov.br/ccivil_03/constituicao/constituicao.htm. Acesso em: 17 mar. 2016. ${ }^{33}$ Citing Daniela Ikawa, Ações afirmativas em universidades (Rio de Janeiro: Lúmen Júris, 2008), 150-52. In: Ibid. 51.

${ }^{34}$ Ibid. 55. 64-65. Citing António Manuel Hespanha, O caleidoscópio do Direito: o Direito e a Justiça nos dias e no mundo de hoje (Coimbra: Almedina, 2007), 238-239. Lewandoski not only cited gender in comparative contexts, but alluded to the struggles of double minorities, black women, who earned less than their white counterparts.

${ }^{35}$ For extensive treatment of the racial and class aspects of the caste system, see B.S. Ghurye,

Caste and Race in India (London: Kegan Paul, Trench, Trubner \& Co., LTD., 1932), 71,96. For a comparative frame see Sidney Verba, Bashiruddin Ahmed, and Anil Bhatt, Caste, race, and politics: a comparative study of India and the United States (Beverly Hills: Sage Publications, 1971), 21-28.
} 
arguments making socioeconomic and racial quotas a zero-sum dilemma.

More generally, Lewandowski cited Brazilian Constitution's Article III which called for the "eradication of poverty and marginalization" alongside the "promotion of the welfare of all" regardless of origin, race, color or age. ${ }^{36}$ Such promotion would fulfill the goal of "equality and justice as supreme values of a fraternal society, pluralist and without prejudice, founded on social harmony" laid out in the 1988 Constitution's Preamble, which encapsulated the "general objectives sought by the Democratic State of Law". The Democratic State of Law also sought to empower, not merely tutor, by helping marginalized groups acquire the technical tools to realize the "potential capacity [quota applicants] contain to intervene in social problems". Citing the need for "a pluralism of ideas", Lewandowski bluntly supported "the methodology of differentiated selection [italics mine]". This method, carried out properly, would "lead to choices centered on the realization of social justice". ${ }^{37}$ The minister occasionally invoked paternal imagery. A key reason for affirmative action stemmed from policy priorities centering, as the Census Bureau put it, "the protection of families and the development of children and adolescents" to facilitate, in Lewandowski's words, "the creation of leadership within these discriminated groups, [leaders] capable of fighting for the defense of their rights, besides serving as paragons of integration and social ascent". ${ }^{38}$ The social "family's" stability (in part his paternal responsibility), as much as Equal Protection, guided Lewandowski.

Lewandowski's view, far from overturning national narratives of social harmony through sinister foreign imports, showed careful attention to legitimate social differences and the resolution of material inequalities actually fulfilled the goals laid out in Brazil's Constitution. The rapporteur's solutions even fulfilled the goal of "social harmony" ostensibly sought by the DEM, as his emphases on meritocracy, minority leadership and the protection of families suggested. By invoking gender difference and the ministers' paternal duties, Lewandowski not only urged subsequent voting ministers to uphold precedent, but also to embrace a vision of constructive, not destructive, difference as a prime category of social and legal analysis.

\footnotetext{
${ }^{36}$ Ibid. 56, 57.. See Article 3: III-IV of the Federal Constitution of Brazil. Disponível em: http://www.planalto.gov.br/ccivil_03/constituicao/constituicao.htm.

37 Ibid. 61-63. Article 1:V, which Lewandowski cited on page 63 calls not for a "pluralism of ideas" but in fact "political pluralism" which implies the ability not only to express ideas, but to implement them in the public sphere. Lewandowski's emphasis on difference seems intentional in this context. He later went on to cite feminist Nancy Fraser and philosopher Axel Honneth's Redistribution or recognition? (2003) in grappling with the importance of "gender difference" in debates around redistributive policies (Ibid. 72). Lewandowski concerned himself with the substantial differences between U.S. and Brazilian legal structures, citing a variety of U.S. affirmative action decisions to highlight "the Brazilian Constitution-it is important to note-permits a wider treatment of affirmative action policies than those main by the Supreme Court of the United States (Ibid. 86)" In fact, the use of the Preamble in the Brazilian Constitution as an interpretive tool of analysis contrasts starkly from the United States, where in 1905, the Supreme Court found that "Although that [U.S. Constitution's] Preamble indicates the general purposes for which the people ordained and established the Constitution, it has never been regarded as the source of any substantive power conferred on the Government of the United States or on any of its Departments". See: 70. Jacobson v. Massachusetts 197 U.S. 22 (1905). Disponível em:

http://readingroom.law.gsu.edu/cgi/viewcontent.cgi?article=1088\&context=buckvbell. Acesso em: 17 mar. 2017. ${ }^{38}$ Ibid. 71.
} 
Luiz Fux, nominated by then-President Dilma Rousseff, cast his vote on his birthday. He turned to a more personal tact than Lewandowski. While Lewandowski had the responsibility of filing the formal report, Fux also maintained the right to give opening commentary before his formal vote. Calling on the justices to give a reading of the case "turned toward the human soul" as a court "turned toward humanity" he recalled his friendship with two prominent black activists, then deceased politician Abdias de Nascimento and Franciscan priest and affirmative action advocate Frei David. ${ }^{39}$ Invoking his personal family history, he compared the historic tragedy of the Holocaust to the plight of Afro-Descendants. On the other hand, he recalled fond memories from his time at the Rio de Janeiro State University (UERJ), teaching "boys and girls [UERJ college students]", who he mentioned in a book preface as "representing the best of him." As part of the Luiz Carpenter Academic Center of the UERJ, they had written a 2012 revolutionarytoned open letter supporting UnB's racial quotas. ${ }^{40}$ Fux's diminutive tone toward his students constituted a performance of masculinity that implied paternalistic affection. By performing his role as an intellectual father and teacher to these students, Fux strengthened his own bona fides as an interpreter of the law, as a compassionate male in his interpersonal relations, and an empathetic judge in his public duties. ${ }^{41}$ Fux turned more explicitly to gender in citing feminist legal scholar Flavia Piovesan's work on "the right to difference". ${ }^{42}$

Fux briefly touched on other controversies surrounding affirmative action. Fux, like Lewandowski, also rejected an Eighteenth-Century individualist interpretation of the Constitution for "discounting the duties which come from Article 3 Section I of the Carta Magna which demands 'a free, just and solidary society."' Later in the text of the decision he emphasized the "comparative institutional advantages" for university institutions that prioritized diversity and reiterated that race was not based on "structures of the human genome" but on social construction. ${ }^{43}$ Drawing on landmark U.S. Civil Rights cases, Fux warned that while "Brown vs. Board of Education" (1954) served as a "watershed case" in applying Equal Protection, "social segregation and discrimination would not be snuffed out with an abstentionist posture". Therefore, the U.S. Supreme Court had justly upheld affirmative action in "Regents of University of California v. Bakke". ${ }^{44}$ Fux argued that recognizing differences would not reinforce racial scientific theories, but rather constitutes a first step towards addressing discrimination based on

\footnotetext{
${ }^{39}$ Ibid. 94, 96-97. He nevertheless made clear that the Court was also acting to resolve a Constitutional question in the absence of direct guidance from Congress and thus, committing itself to judicial restraint.

${ }^{40}$ Ibid. 100-1.

${ }^{41}$ Richard Collier, Men, Law and Gender: Essays on the 'Man' of Law (New York: Routledge, 2010), 18,25.

42 Ibid. 110 citing Piovesan, Flávia. “Ações Afirmativas: A Questão das Cotas”. In: Renato Ferreira (Coord.) Ações afirmativas no Brasil: desafios e perspectivas (Niterói: Impetus, 2011) p. 118-119. See also: Flavia Piovesan "Acoes afirmativas no Brasil: Desafios e Perspectivas.” Estudos Feministas, Florianópolis, 16(3): 424, setembrodezembro/2008

${ }^{43}$ Ibid. 111, 115,118. The reference to the human genome seemed to allude to the DEM's argument, at least as characterized by Fux, that race did not exist because scientists could not detect differences in the human genome. This argument would still use biological factors to adjudicate the racial question and thus Fux deemed it invalid. ${ }^{44}$ Ibid. 8-9.
} 
the socially-existent category of race.

Rosa Weber, a Lula nominee, concisely focused on classic proof for racial discrimination in Brazil. She briefly mentioned that Afro-Brazilians continued to be underrepresented at Federal universities. Turning to the international arena, Weber reminded justices that Rwanda's racial classifications were socially-based, not biologically-based and noted the 1940 and 1950 studies of Oracy Norgueira, distinguishing between discrimination due to ancestry in the United States and discrimination based on phenotype in Brazil. ${ }^{45}$ Weber's opinion did not explicitly mention gender, but did put emphasis on social construction as a useful lens through which to view, analyze and recognize racial discrimination.

Minister Carmen Lúcia (who became STF President in 2016), a Lula appointee, opened her pre-vote comments taking an unusually conciliatory tone, going out of her way to iterate that "those who have a contrary understanding to mine do not fail to deserve my respect and my understanding". After a deferential opening, Minister Lúcia contrasted "formal equality" with the process of "dynamic equalizing" in which the Court was then participating. ${ }^{46}$ Equality then was not a universal principle but an ongoing and changing process. She then turned to personal matters, citing an experience when one of her nieces, who was black, rejected a black doll that Lúcia had gifted her (another white niece had proudly accepted the exact same doll). Lúcia also recounted the story of a black elementary school girl who asked Lúcia to buy a sandwich for her with the girl's own money because the girl was afraid the elementary school officials "would think the money is not mine" were she to enter the cafeteria. ${ }^{47}$ It's hard to know whether Fux's invocation of the Brown decision spurred the minister's memory of dolls, but her invocation of inaccessible lunch counters and doll tests perhaps suggested that the world of the segregated United States, long deplored and looked down upon by elite Brazilian intellectuals, was not so far away from home.

Lúcia emphasized that such experiences, in addition to "experiences that I lived in my house, are not observed from a distance". These personal experiences led Minister Lúcia to the conviction that "in a democracy, we do not give to each individual that which is his or hers, but rather, adopt policies to give to each according to his/her necessity". ${ }^{48}$ Minister Lúcia, structuring her argument according to Lewandowski's report and vote reasoning, said that discourse on formal inequality constituted "repeated rhetoric, agreed upon in language, but eluded in practice". Minister Lúcia also emphasized the importance of embracing identity difference, the need for society to "become aware of the need to respect identities on those factors that distinguish us as intrinsically human, but [also] in peculiarities" restating "we are all equal, but we are also

\footnotetext{
45 Ibid. 125-6,129.

${ }^{46}$ Ibid. 131-2.

${ }^{47}$ Ibid. 133.

${ }^{48}$ Ibid. $134-5$
} 
unique". ${ }^{49}$ Minister Lúcia repeated her belief in "dynamic equality, which changes to transform our society... which is not only a guideline and advice, but also a rule..." Citing legal scholar Boaventura de Sousa Santos (a key scholar in affirmative action historical debates) the minister rejected the notion that legislators and judges could address racial discrimination with solutions based solely on class. ${ }^{50}$ Fundamentally, "constitutional dynamism" came down to the "right to be, and on top of that, to be different, [with] guaranteed identities..." because " [Lúcia repeats] in democracy, we do not give to people what belongs to them, but adopt policies to give to each one according to necessity". 51

Minister Lúcia's emphasis on the personal as opposed to the abstract creates an interesting tension with her assertion that the state has an expressed responsibility to intervene, even at the cost of the individual's ownership, in order to satisfy the needs of society. Thus, in Minister Lúcia's decision, individual private difference and collective political and economic rights both functioned in paradox to fulfill the mandates of non-discrimination, perhaps lending credence to Carol Hanisch's adage that "the personal is political". ${ }^{52}$ Minister Lúcia's story of the dolls invoked both a maternal instinct (the desire to protect her nieces from the ravages of racial bias). The example also suggested that the United States of "Brown v. Board" was not so far away from the Brazil of 2012 as racial exceptionalists would have hoped. ${ }^{53}$ The example served another purpose: To perform an "authentic" feminine role in a masculine space ${ }^{54}$ Perhaps she hoped that her colleagues would find a deferential tact and maternal performance more persuasive than invoking the paternal duties of the law.

Surprisingly, Joaquim Barbosa, a Lula appointee and Brazil's first Afro-Brazilian Supreme Tribunal minister, and soon-to-be Chief of the STF (2012-2014), deferred to Lewandowski's vote. "I have nothing further to add to the exhaustive and excellent vote of Minister Lewandowski...Your Excellency's vote is not only convincing, but also wide ranging and in complete harmony with the most modern literature on the topic". ${ }^{55}$ Perhaps his historic

\footnotetext{
${ }^{49}$ Ibid. $137-8$.

${ }^{50}$ Ibid. 139, 145 Lúcia citing SANTOS, Boaventura de Sousa, A Universidade no século XXI: para uma reforma democrática e emancipatória da Universidade (São Paulo: Cortez, 2004), 69

${ }^{51}$ Ibid. 153.

${ }^{52}$ See: Carol Hanisch, "The Personal is Political" in Radical Feminism: A Documentary Reader, ed. Barbara A. Crow (New York: New York University Press, 2000).

${ }^{53}$ Minister Lúcia's invocation of dolls would have special significance in the United States. The Clark Doll Test, concluded that even black children, when presented with black and white identical dolls, preferred the white one. Lúcia's story deviates only insofar as her white niece liked the black doll. Mamie and Kenneth Clark testified in the lower court case that would become Brown v. Board. For the details of the test, see: Kenneth B. Clark and Mamie P. Clark, "Emotional Factors in Racial Identification and Preference in Negro Children" The Journal of Negro Education, Vol. 19, No. 3, The Negro Child in the American Social Order (Summer, 1950):341-350. For details on their testimony, see: Beggs, Gordon J. "Novel expert evidence in federal civil rights litigation." American University Law Review 45 (1995):10-11.

${ }^{54}$ The courtroom, like the political rallies in Madeline Pelltier's novels, functions as a male space in which women are encouraged to either take the poses of a man or take on traditionally feminine rolls when addressing largely male audiences. See: Joan Scott, The Fantasy of Feminist History, Next Wave Provocations (Durham: Duke University Press, 2011), 56-7.

${ }^{55}$ Ibid. 154. He also possibly said this in order to create a sense of unity, and thus, momentum for the ministers voting later in the sequence, as peers would not want to end up on the wrong end of a lopsided decision in a historic
} 
presence in the chamber and his prior scholarship (which Lewandowski had cited) made a lengthy statement unnecessary. Perhaps he felt a long statement by a black justice on affirmative action would polarize the court threaten the potential ideological consensus. Whatever the reasons for his brevity, Barbosa's statement highlighted the great impact that Lewandowski's report and vote had on the court. It also spoke to the institutional power of the Relator in framing the debate.

Cezar Peluso, another Lula appointee who had previous conflicts with Joaquim Barbosa over Peluso's tenure as STF president, nevertheless, "endorsed the words" of the minister praising Lewandowski's thoroughness. However, he found it necessary "to express [his] own thoughts on the matter" ${ }^{56}$ His vision sought to protect both racial and gender minorities in the same way that the state protected children or the disabled. Peluso cited the "infra-constitutional legislation" such as the domestic violence Maria da Penha law and articles of the Constitution that "tutor[ed] classes or groups in situations of socioeconomic vulnerability" and gave "exception treatment" to "women", "minors" and "handicapped" citizens. Peluso endorsed reserving quotas for "needy or poor children". 57

Several issues stand out here. Peluso cited Article 7 Section XX referring to the "protection of the women's workforce" through "specific incentives". Article 7 more generally speaks of "rural and urban workers"" and their "right to improve their [own] social condition". One sees a difference in the general article's vision of workers' agency (workers "improve their social condition") and paternalism toward certain protected classes. In this case, it was "protection" of women and their work environments. ${ }^{58}$ Peluso's statements seemed to touch the heart of the latter vision.

Peluso separated the socioeconomically vulnerable from other vulnerable classes like "women, minors, and the handicapped" indicating that affirmative action was a way of "protecting" women as women and not simply making up for socioeconomic harm caused by systemic disadvantages. For Peluso, restorative justice did not constitute the center of affirmative action policy as much as the need to protect "persons in vulnerable situations". The Maria da Penha Law, which Peluso cited next, sought to "repress" domestic violence against women. ${ }^{59}$ While the law followed in a line of international progressive laws on domestic violence, the Constitutional article it invoked as its foundation, Article 226, states that "The family is the foundation of society with special protection of the state". Confirming the articles traditional purposes, Section 3 of Article 226 affirms the state's role in promoting the marriage of one man

\footnotetext{
case.

${ }^{56}$ Ibid. 155.

${ }^{57}$ Ibid. 156-57.

${ }^{58}$ Artigo 7, Sec. XX. Constituição da Republica Federativa do Brasil (1988). Disponível em: http://www.planalto.gov.br/ccivil_03/constituicao/constituicao.htm. Acesso em: 18 mar. 2017.

${ }^{59}$ Art. 1, Lei 11.340. 7 de Agosto de 2006. Disponível em: http://www.planalto.gov.br/ccivil_03/_ato20042006/2006/lei/l11340.htm. Acesso em: 18 mar. 2017.
} 
and one woman for the growth of a family. ${ }^{60}$ It seemed that corporatist concepts, not pluralist visions, guided Peluso's reasoning.

Despite this seemingly philosophical conservatism, after brief interjections from Joaquim Barbosa and Gilmar Mendes on the divide between private and public educational institutions in Brazil, Peluso ended his remarks more or less on terms similar to those of his predecessors. ${ }^{61}$ Drawing on Weber's point distinguishing phenotypic and ancestral discrimination, Peluso chided quota opponents for over-emphasizing the material difference between race and ethnicity. He also factored in the "historical obstacles" facing protected classes seeking to access and benefit from higher education. Ending more or less on the theme of "necessity" versus "ownership" highlighted by Minister Lúcia, Peluso delivered a final blow to the merit argument. "It is not possible, therefore, to use this same criteria for those that, in their past, did not have equal objective conditions to now support judgment by that criteria in the name of justice". ${ }^{62}$ After delivering an unequivocal phrase, he delivered his affirmative vote, continuing the streak of unanimity.

What made Peluso such a unique case in connecting race and gender? While reasoning at the intersection of gender and racial justice generally promoted the vision of a plural democratic society, Peluso's vote suggested a judges' paternalism - not only sympathies - regarding intersectional politics, can drive legal minds to make these connections. While a nagging question may remain as to whether one can truly be "equal" under a government more interested in "protecting" than "empowering" vulnerable social classes, the use of blatantly paternalistic discourse to advocate for intersectional politics remains an interesting tension between theories of human agency and the practicalities of constructing discourses of legal guarantee.

Gilmar Mendes, an appointee of Fernando Henrique Cardoso, and the most quotaskeptical judge of the STF at that time, opened his pre-vote commentary lauding the "magnificent vote brought by the eminent rapporteur [Lewandowski]" and proceeded to follow up on Peluso's discussion of the Maria da Penha law, which he said, showed that "the very Constitution foresees measures of social assistance...contemplating the situations of those who, in some way, find themselves in some deficient relations". ${ }^{63}$ Mendes then narrowed the discussion to the question of racial tribunals and race specifically (claiming that the UnB "adopted exclusively racial criteria") saying the third party commissions to verify self-identified Afro-Brazilians remained “difficult to justify". During a heated debate with Supreme Court President Ayres Britto, Mendes cited the example of a 2004 case where twins applied to the UnB under the quota system, and administrators accepted one, and rejected the other. When Britto responded that being black and

\footnotetext{
60 Art. 226 Sec. 3, 8. Constituição da Republica Federativa do Brasil (1988). Disponível em: http://www.planalto.gov.br/ccivil_03/Constituicao/Constituicao.htm\#art226\$8 Acesso em: 18 mar. 2017.

${ }^{61}$ Ibid. 156-60.

${ }^{62}$ Ibid. 162

${ }^{63}$ Ibid. 163-4.
} 
poor was "an inequality within an inequality" (not the same as being poor and white) Mendes retrenched in his position, continuing to argue that Afro-Brazilians attending private schools would fare better than poor whites attending public schools. ${ }^{64}$ Evaluating the racial quotas apart from socioeconomic ones "would lead me to vote for the furtherance of this petition [against the quotas]" ${ }^{65}$ It seemed that the most conservative justice on the court would not bow easily to the early momentum favoring the UnB system. Despite arguments about collective rights, Mendes appeared ready to disregard historical discrimination and affirm constitutional individualism.

Surprisingly, however, Minister Mendes opted to support affirmative action precedent, referencing the "substantial number of $[\mathrm{STF}]$ decisions" legitimizing various methods of affirmative action under the principle that formal equality (quoting Anatole France) "assured the poor and the rich [equal opportunity to sleep under the bridge]". ${ }^{66}$ In order to overcome his objection to the lack of socioeconomic quotas, he would rely on the judicial concept of "intermediary sentencing" which allowed for the possibility that policies and even the meaning of judicial concepts, would progress as historical conditions evolved. ${ }^{67}$ This view of the law bears much similarity to Gail Hershatter's scholarship seeking to "introduce a bit of disquiet by suggesting that we think of gender not as a structure, but rather as a fractured, unpredictable, and expansive terrain. In doing so, we can find new and more varied lodging places for gender as a category of historical analysis". ${ }^{68}$ Moving into his official vote, Mendes proposed looking at affirmative action "in the light of Liberty, Equality, and Fraternity". For him, legal interpretation adhered to fundamental precepts even as those precepts themselves changed over time. Additionally, Mendes described, in substance, Darcy de Oliveira's "equality trap" as "the equality paradox" in which formal equality resulted in de facto material inequality and material equality resulted in formal inequality. ${ }^{69}$ Despite these admissions, Mendes' support for quotas seemed forced. He argued that the Brazilian state had never implemented formal segregation (and had actually fought against it) until the cultural affirmation policies of the Fernando Henrique Cardoso administration and the implementation of separate lines during the quota process. He also argued that decisions on blackness had become politicized and supported DEM's assertion that the statistics proving historic discrimination had been "manipulated" $\cdot{ }^{70}$ Despite all of his reservations,

\footnotetext{
${ }^{64}$ Ibid. 166-7.

${ }^{65}$ Ibid. 168.

${ }^{66}$ Ibid. 169.

${ }^{67}$ Ibid. 170.

${ }^{68}$ Gail Hershatter, "Disquiet in the House of Gender" The Journal of Asian Studies Vol. 71,4 (November 2012): 877.

${ }^{69}$ Ibid. 177, 179 Mendes citing ALEXY, Robert, Teoría de los derechos fundamentales (Madrid: Centro de Estudios Políticos y Constitucionales, 2001).

${ }^{70}$ Ibid. 182-85, 187, 189, 191, 199. Mendes even quoted controversial African-American economist Thomas Sowell, who drew both praise and fire for his comparative work arguing the ineffectiveness of affirmative action. Ibid. 193 Mendes citing SOWELL, Thomas, Ação Afirmativa ao redor do mundo: estudo empírico. Trad. Joubert de Oliveira Brízida. $2^{\mathrm{a}}$ ed. (Rio de Janeiro: UniverCidade Editora, 2004), 2. Feminist economist Cecilia A. Conrad wrote, "[Affirmative Action Around the World] is sure to provide fodder for conservative pundits, but it offers little to advance economic scholarship on this issue". Cecilia A. Conrad, Review of Affirmative Action Around the World: An Empirical Study. By Thomas Sowell (New Haven, CT: Yale University Press, 2004). The Journal of Economic
} 
however, he opted ultimately to embrace the quotas as a trial of "institutional experimentalism" that would challenge "the civil religion" of the law. In other words, Mendes preferred a "prospective" as opposed to "retrospective" view of the law. That legal view -- combined with his pride that "the UnB was a pioneer in the formulation" of affirmative action -- superseded his objections on the merits. ${ }^{71}$ Thus for Mendes, the "equality paradox" played a key role in coming to terms with systemic inequality and the need to address it through institutional entrepreneurial means, even means that cast doubt on the notion of individual meritocracy.

Minister Marco Aurélio, nominated by his cousin and eventually impeached President Fernando Collor, began his vote by comparing Brazil's higher education system unfavorably to Argentina's, which lacked a national entrance exam. He also pointed out his proposal to expand affirmative action policies in the private sector as well as the universities. ${ }^{72}$ By pointing this out immediately, the judge immediately made clear his vision on how race and class intersected in this case, which served as a direct rebuke to the DEM's attempts to separate them. Like other judges, Aurélio weighed in on the origins of affirmative action, tracing them back to 1968 with Brazil's ratification of the International Convention on the Elimination of all Forms of Racial Discrimination. Aurélio, like Chief Minister Lewandowski, recognized the intersectional concerns laid out in the Preamble to the Brazilian Constitution which guaranteed both "individual and social rights" founded on "social harmony...under the protection of God". Unlike Lewandowski, Aurélio incorporated religious universalist language into his Preamble citation, drawing on a long tradition of Catholic human rights that nevertheless implied an overall conservative position. ${ }^{73}$ Minister Aurélio also drew on the concept of "efficacious, dynamic equalization" which should "'construct, 'guarantee', and 'promote"” implying "a posture [which] ought to be affirmative". ${ }^{74}$ Aurélio also drew heavily on the case and statutory law surrounding gender. Pointing to precedent supporting legislative gender quotas, Article 7 regarding the "protection of women" in the workforce, and a law (8.666/93) protecting the disabled, Aurélio directly argued "that the practice of affirmative action in the public universities is a latent possibility in the constitutional rules and principles applicable to the subject [italics mine]" ${ }^{75}$ That the "rules and principles applicable" to the racial quota case before him happened to be statutory law on protecting women and the disabled hardly seemed to be a coincidence. Neither

\footnotetext{
History 64,4 (December 2004): 1157. She seems to have been prophetic on the first point.

${ }^{71}$ Ibid. 204-5,208.

${ }^{72}$ Ibid. 209. Although they do not have a national entrance exam, Argentine universities do have individual entrance exams for professional schools such as Medicine.

${ }^{73}$ Ibid. 212. The judge, nominated by Fernando Collor, had at one point called the 1964 military coup and subsequent military regime "a necessary evil" See: Eduardo Maretti, "Marco Aurélio volta a defender golpe de 64: 'Sem a revolução, o que teríamos?"' Rede Brasil Atual October 23, 2012. Disponível em: http://www.redebrasilatual.com.br/politica/2012/10/julgamento-do-mensalao-201ce-estritamente-tecnico201d-dizmarco-Aurélio-mello. Acesso em: $1 \mathrm{abr}$. 2017. On the relationship of Catholicism and Protestantism to human rights see: Samuel Moyn, Christian Human Rights (Philadelphia: University of Pennsylvania Press, 2015).

${ }^{74}$ Ibid. 213.

${ }^{75}$ Ibid. 216-7.
} 
did the judge's invocation of "dynamic equalization" that is, constantly changing identities. This same justice who had supported the amnesty laws for military officials in the name of "turning the page" on the past called for compassion above "judicial dogmatism", rebuked, citing the words of his colleague Minister Lúcia, "the silence of whites with blacks and the soft words with women", and lauded affirmative action for aiding in advancing the potentially post-racial politics of U.S. President Barack Obama. ${ }^{76}$ Clearly, even this conservative member of the court, who had just years before defended the military regime, seemed convinced of the constitutionality and the inevitable march of progress that legally empowering marginalized identities represented. Interestingly, like Mendes, he ruled based on theories of identity instability and development, even while turning to paternal gendered precedents to justify his vote.

Supreme Tribunal President Ayres Britto, also nominated by Lula, was the last to vote. ${ }^{77}$ Also invoking the Preamble, Britto argued for the necessity of redistributive justice. Drawing upon the Catholic tradition as well, Britto referred to the words of Augustine of Hippo "without a minimum of material welfare, one cannot even serve God". ${ }^{78}$ Britto's vision of the nation as "a river, one river from the source to the mouth...from the first to last generation" only reinforced the imagery of a nation at once united and changing. Drawing on gendered language, the author speaks of the equalizing of material factors as "social inclusion" and community integration into the body politic as "fraternal integration". Hitting back at a false sense of "racial harmony" however, Britto pointed to Brazil's criminalization of racism as a proof for its existence and also pointed to the pluralism mandated in Article III of Brazil's Constitution as a grounds for affirmative action generally, and quotas specifically, for every category of disadvantaged group. ${ }^{79}$ Britto also connected race and gender. "The color of one's skin is like the gender that one carries or your place of birth - [one's] geographic origin". ${ }^{80}$ In short, Britto tied race and gender together as inevitable human variances, socially immutable characteristics that nevertheless incurred discrimination and required redress. Britto, nevertheless echoed Brazil's founding motto of "Order and Progress", lauding Brazil's "humanistic Constitution" which had allowed (with Britto's own vote) unanimous ruling, a moment constituting "one more motive to look into the

\footnotetext{
${ }^{76}$ Ibid. 218-19. For Aurélio's comments on amnesty, see: Sonia Racy, ““A Lei da Anistia é uma virada de página. Não há mais como mudá-la'.” Estado de São Paulo December 8, 2014. Disponível em: http://cultura.estadao.com.br/blogs/direto-da-fonte/a-lei-da-anistia-e-uma-virada-de-pagina-nao-ha-mais-como-mudala/. Acesso em: 1 abr. 2017.

${ }^{77}$ Minister José Celso de Mello Filho canceled his voto (although he also voted yes in the proceedings according to news reports). Dias Toffoli recused himself from the case. This left a 10-0 margin in the original vote count, and a 90 margin in the acórdão with Celso de Mello's cancellation.

${ }^{78} \mathrm{Ibid}$. 221. I have so far not been able to verify this quote. The only other place it appears is another Britto decision before the Brazil's Supreme Labor Court (TST). Disponível em: http://www.tst.jus.br/home?p_p_id=15\&p_p_lifecycle=0\&p_p_state=maximized\&p_p_mode=view\&_15_struts_acti on=\%2Fjournal\%2Fview_article\&_15_groupId=10157\&_15_articleId=8777362\&_15_version=1.4.

${ }^{79}$ Ibid.224, 227,228. For more on the relationship between landscape and metaphors of national inclusion and exclusion see: Thomas D. Rogers, The deepest wounds: a labor and environmental history of sugar in Northeast Brazil. Chapel Hill: University of North Carolina Press, 2010.

${ }^{80}$ Ibid. 231.
} 
mirror of history and not blush with shame." ${ }^{81}$ Britto, with his vote and statement, had declared a major victory in Brazil's long struggle to accept its deep differences while at the same time invoking the better angels of the country's nature, its potential social harmony.

\section{Conclusion: where from here?}

This article laid out the multiple rationales that led to this incredible moment of clarity and consensus on the meaning of Brazil's Constitution. Affirming the common critical potential of race and gender served as one of the principle judicial means of incorporating positive discrimination into Brazil's narrative of national progress and serves as an example to feminist and critical race scholars debating the potential of "difference" in promoting joint analysis. ${ }^{82}$ While this ruling came down in a Brazilian court, it quite literally re-litigated the affirmative action debates in the United States, from "Brown to Bakke". In the early 1940s and 1950s, historians from around the world, including many U.S. and Brazil historians, looked to Brazil as an example of racial reconciliation, but later faced the reality of a discovered discrimination just as insidious as in the segregated U.S. This ruling provides historians, not just current policy makers, and the chance to rethink yet again Brazil's contributions to the fight for racial justice. In a case where Brazil's history was at stake, Brazilian justices, eight of eleven of them white men, chose to accept a Brazilian past that admitted racial guilt, past and present, as opposed to a historical denial that would impede progress. Further scholarship might consider what historical conditions have changed in Brazil, such that in this instance, the Brazilian courts took a truly more circumspect view of their own racial past and present than the U.S. Supreme Court took in prior decades. ${ }^{83}$ Does this represent a shift in Brazilian historical thought, or merely the reappearance of a long line of alternative histories of Brazilian race relations? Turning to policy, how does this reasoning on this case apply to current governmental efforts, from all three branches, to consolidate education expansion and access laws established in previous governments? ${ }^{84}$ How does it pertain to the legal rationale for budget measures, measures which some legal experts

\footnotetext{
${ }^{81} \mathrm{Ibid}$.

82 While the move to analyze gender and race through "difference" has significant support among scholars, crossanalysis of gender and racial struggles has not always been associated with progress narratives. As Robyn Wiegman writes, some saw the institutional highlighting of "difference" and joining the categories of race and gender as "the progress of gender's most persistent threat". See: Robin Wiegman, Object lessons, Next Wave: New Directions in Women's Studies (Durham: Duke University Press, 2012), 50.

${ }^{83}$ Even the 2016 U.S. Fischer ruling upholding the University of Texas" "holistic" affirmative action process relied on the least effective (vaguest and hardest to prove) justification for affirmative action, that is, diversity's benefits to the institution. See "Opinion of the Court". Fisher v. University of Texas at Austin. 579 U.S. 12-13 (2016). Disponível em: https://www.supremecourt.gov/opinions/15pdf/14-981_4g15.pdf. Acesso em: 7 jun. 2017.

${ }^{84}$ See: "Plenário declara constitucionalidade da Lei de Cotas no serviço público federal” Noticias STF, 8 jun. 2017. Disponível em: http://stf.jus.br/portal/cms/verNoticiaDetalhe.asp?idConteudo=346140. Acesso em: 4 set. 2017. See also: José Mendonça Bezerra Filho, "Reunião de Comparecimento com a presença do Sr. José Mendonça Bezerra Filho, Ministro de Estado da Educação“ Requerimento $n^{\circ}$ 254/2017 - CE, do Deputado Caio Narcio. Requerimento $n^{\circ}$ 317/2017 - CFFC, do Deputado Wilson Filho, 17 maio, 2017. Disponível em: http://www2.camara.leg.br/atividadelegislativa/webcamara/videoArquivo?codSessao=65568. Acesso em 7 jun. 2017.
} 
allege disproportionately cut programs benefiting Brazil's most vulnerable? ${ }^{85}$ Whatever the answers, this case has opened the door to rethink Brazil's role on the world stage, its approach to race, and its role in the struggles for racial justice and a better understanding of global racial histories.

\section{Bibliography}

ALEXY, Robert. Teoría de los derechos fundamentales. Madri: Centro de Estudios Políticos y Constitucionales, 2001.

ARAÚJO, Clara. Mulheres e representação política: a experiência das cotas no Brasil. Estudos Feministas, v. 6, n. 1, p. 71-90, 1998. Disponível em: 7190.http://www.jstor.org/stable/43904024. Acesso em: 27/06/17

ARAÚJO, Clara. Potencialidades e limites da política de cotas no Brasil. Estudos Feministas, v. 9, n. 1, p. 231-252, 2001.

ARAÚJO, Clara. Rotas de ingresso, trajetórias e acesso das mulheres ao legislativo-um estudo comparado entre Brasil e Argentina. Estudos Feministas, v. 18, n. 2, p. 567-584, maio/ago. 2010.

AZEREDO, Sandra. Mestiçagem, igualdade e afirmação da diferença-pensando a política das cotas na universidade. Estudos Feministas, v. 13, n. 3, p. 738-755, set./dez. 2005.

BASTIDE, Roger. The African religions of Brazil: toward a Sociology of the interpenetration of Civilizations. Baltimore: Hopkins University Press, 1978.

BLAKE, William D.; HACKER, Hans J. 'The Brooding Spirit of the Law': Supreme Court Justices Reading Dissents from the Bench.” The Justice Center Journal 31, 1 (2010): 1-25.

BOURDIEU, Pierre; WACQUANT, Loic. On the Cunning of Imperial Reason. Theory, Culture, and Society, Vol. 16, No.1 (1999)

CARDOSO, Fernando Henrique. Capitalismo e escravidão no Brasil meridional: o negro na sociedade escravocrata do Rio Grande do Sul. Rio de Janeiro: Difusão Europeia do Livro, 1962.

COLLIER, Richard. Men, Law and Gender: Essays on the 'Man' of Law. New York: Routledge, 2010.

CRENSHAW, Kimberle. Mapping the Margins: Intersectionality, Identity Politics, and Violence against Women of Color. Stanford Law Review, 43,6 (Jul. 1991).

DAFLON, Veronica Toste; FERES JÚNIOR, João; CAMPOS, Luiz Augusto. Fora de quadro: a ação afirmativa nas páginas d'O Globo. Revista Semestral do Departamento e do Programa de Pós-Graduação em Sociologia da UFSCar, Vol. 1, no. 2 (2012): 61-83.

DAFLON, Veronica Toste; FERES JÚNIOR, João; CAMPOS, Luiz Augusto. Ações afirmativas raciais no ensino superior público brasileiro: um panorama analítico. Cadernos de Pesquisa 43, no. 148 (2013): 302-327.

BARRETO, Paula Cristina da Silva. Gênero, raça, desigualdades e políticas de ação afirmativa no ensino superior. Revista Brasileira de Ciência Política, Vol. 16 (2015): 39-64.

DEGLER, Carl. Neither Black nor White: Slavery and Race Relations in Brazil and the United States. New York: Macmillian, 1971.

\footnotetext{
${ }^{85}$ See: Ronaldo Jorge Araujo Vieira Junior, “As Inconstitucionalidades do 'Novo Regime Fiscal' Instituído pela PEC №55, de 2016 (PEC N 241, de 2016, na Câmara do Deputados), Boletim Legislativo, 53, p. 23-25, nov. 2016. Disponível em: http://www12.senado.leg.br/publicacoes/estudos-legislativos/tipos-de-estudos/boletinslegislativos/bol53. Acesso em: 7 jun. 2017.
} 
MACEDO, Felipe; FONSECA, Gabriel Ferreira. O papel transformador do Direito: ações afirmativas e inserção das mulheres na política brasileira. FIDES: Revista de Filosofia do Direito, do Estado e da Sociedade Vol. 1, no. 2 (2010): 125-142.

DUARTE, Evandro Piza; SCOTTI, Guilherme. História e memória nacional no discurso jurídico: o julgamento da ADPF 186. Universitas JUS 24:3 (2013): 33-45.

HELGA, Paula P. A Política De Cotas Para Mulheres no Legislativo, o Feminismo e as Ações Afirmativas. Revista De Administração Pública 38, no. 6 (Nov, 2004): 1109-1122.

FERNANDES, Florestan. A Integração do negro na sociedade de classes. I, O Legado da "raça branca [S.I]: Dominus Editoria, 1965.

FRENCH, John D. Passos em Falso da Razão Antiimperialista: Bourdieu, Wacquant, e o Orfeu e o Poder de Hanchard. Estudos Afro-Asiáticos, Ano 24, 1 (2002):97-140

GHURYE, B.S. Caste and Race in India. London: Kegan Paul, Trench, Trubner \& Co., LTD., 1932.

HANISCH, Carol. The Personal is Political, in CROW, Barbara A (org.). Radical Feminism: A Documentary Reader. New York: New York University Press, 2000.

HÉBRARD, Jean M. Slavery in Brazil: Brazilian Scholars in the Key Interpretive Debates. Translating the Americas 1, 2013.

HERSHATTER, Gail Disquiet in the House of Gender. The Journal of Asian Studies Vol. 71, 4 (November 2012).

HESPANHA, António Manuel. O Caleidoscópio do Direito - O Direito e a Justiça nos dias e no mundo de hoje. Coimbra: Almedina, 2007.

IKAWA, Daniela. Ações Afirmativas em Universidades. Rio de Janeiro: Lúmen Júris, 2008.

MINHOTO, Antonio Celso Baeta. Da escravidão às cotas. São Paulo: Boreal, 2013.

MOEHLECKE, Sabrina. Ação afirmativa: história e debates no Brasil. Cadernos de pesquisa 117, no. 11 (2002): 197-217.

MOUNTIAN, Ilana; CALVO-GONZALEZ, Elena. II.'Race', class and affirmative action in Brazil: Reflections from a feminist perspective. Feminism \& Psychology Vol. 22, no. 2 (2012): 240-248.

MOYN, Samuel. Christian Human Rights. Philadelphia: University of Pennsylvania Press, 2015.

OLIVEIRA, Darcy de. In Praise of Difference: The Emergence of a Global Feminism Piscataway, NJ: Rutgers University Press, [1998] 2000.

PAIXÃO, Marcelo. Waiting for the Sun: An Account of the (Precarious) Social Situation of the African Descendant Population in Contemporary Brazil. Journal of Black Studies Vol. 34, no. 6 (2004): 743-765.

PIOVESAN, Flávia. Ações Afirmativas: A Questão das Cotas. In: FERREIRA. Renato (org.) Ações afirmativas no Brasil: desafios e perspectivas. Niterói: Impetus, 2011.

RADOMYSLER, Clio Nudel. STF: Um espaço de luta do movimento negro. Revista Direito e Práxis 4:6 (2013): 31-51. 
RIBEIRO, Carlos Costa; Schlegel, Rogerio. Estratificação horizontal da educação superior no Brasil (1960 a 2010). In: ARRETCHE, Marta. Trajetórias das desigualdades, como Brasil mudou nos últimos 50 anos. São Paulo: UNESP, 2015.

ROGERS, Thomas D. The Deepest Wounds: A Labor and Environmental History of Sugar in Northeast Brazil. Chapel Hill: University of North Carolina Press, 2010.

ROSEMBERG, Fúlvia; ANDRADE, Leandro Feitosa. Ação afirmativa no ensino superior brasileiro: A tensão entre raça/etnia e gênero. Cadernos Pagu Vol. 31 (2008): 419-437.

SANTOS, Boaventura de Sousa. A Universidade no século XXI: para uma reforma democrática e emancipatória da Universidade. São Paulo: Cortez, 2004.

SCOTT, Joan. The Fantasy of Feminist History, Next Wave Provocations. Durham: Duke University Press, 2011.

SILVERIO, Valter Roberto. Ação afirmativa e o combate ao racismo institucional no Brasil. Cad. Pesqui. [online].117 (2002):219-246.

SILVÉRIO, Valter Roberto. As cotas para negros no tribunal: A audiencia pública do STF. São Carlos: EDUSFCar, 2012.

SISS, Ahyas. Afro-brasileiros, cotas e ação afirmativa: Razões históricas. Rio de Janeiro: PENESB-UFF, 2003.

TANNENBAUM, Frank. Slave and Citizen. Boston: Beacon Press, 1946.

TOPLIN, Robert. The Abolition of Slavery in Brazil. New York: Atheneum, 1972.

VERBA, Sidney; AHMED Bashiruddin; BHATT Anil. Caste, Race, and Politics: A comparative Study of India and the United States. Beverly Hills: Sage Publications, 1971.

VIEIRA JUNIOR, Ronaldo Jorge Araujo. As Inconstitucionalidades do 'Novo Regime Fiscal' Instituído pela PEC N ${ }^{\circ} 55$, de 2016 (PEC N² 241, de 2016, na Câmara do Deputados). Boletim Legislativo 53 (Nov. 2016): 23-25.

WIEGMAN, Robin. Object Lessons Next Wave: New Directions in Women's Studies. Durham: Duke University Press, 2012. 